\title{
DESAIN DINDING PENAHAN TANAH SEBAGAI PERKUATAN PADA KELONGSORAN VILLA DI HAMBALANG
}

\author{
Abi Maulana Hakim ${ }^{1)}$ \\ ${ }^{1}$ Program Studi Teknik Sipil, Institut Teknologi Indonesia, email: abimaulanahakim@gmail.com
}

\begin{abstract}
Abstrak
Kelongsoran merupakan salah satu masalah yang muncul saat musim hujan. Masalah ini sudah lazim terjadi dan dapat dicegah dengan membuat perkuatan struktural pada area rawan longsor sebelum terjadi kelongsoran. Metode ini efektif sebab perkuatan dirancang memotong garis kelongsoran, sehingga memperkuat tanah tersebut. Secara umum, sebelum terjadi kelongsoran akan muncul indikasi seperti tanah retak, retak struktur, pergerakan vegetasi, dsb. Dengan mengamati kejadian ini dapat diprediksi bahwa pergerakan tanah lebih besar akan terjadi. Oleh sebab itu, tindakan pencegahan harus dilakukan. Paper ini membahas satu studi kasus di Hambalang, Bogor, Jawa Barat, Indonesia. Pada kasus ini, keretakan struktur ditemukan pada beberapa tempat, terutama pada area kolam renang. Hal ini muncul sejak awal tahun, bertepatan dengan curah hujan intensitas tinggi, yang diperkirakan menjadi penyebabnya. Analisis dilakukan untuk mengevaluasi stabilitas lereng yang ada dan didapat angka keamanan sebesar 1.181. Selanjutnya, perkuatan didesain sebagai pencegahan. Perkuatan berupa dinding penahan tanah yang berbentuk capping beam dengan cukup tebal dan ditopang oleh pondasi tiang bor. Berdasarkan hasil analisis, angka keamanan meningkat menjadi 1.553 pada kondisi kritis. Nilai ini diatas kriteria minimum, 1.5, dan disimpulkan sebagai desain yang aman. Kapasitas struktural tiang bor juga didesain. Kemudian, dinding penahan tanah dikonstruksi di lapangan sebagai tahap akhir dari pengabdian masyarakat.
\end{abstract}

Kata kunci: Stabilitas Lereng, Struktur Penahan Tanah, Tiang Bor

\section{Abstract}

Landslide is one of major issues that occurred during rainy season. This problem is straightforward and able to be prevented by installing reinforcement into the designated landslide location. It is effective due to the reinforcement cutting through failure plane, hence strengthen the soil body. By and large, prior to land sliding, several indications are taken into place, such as soil cracking, structural cracking, vegetation movement, etc. Further soil movement are very likely to follow afterwards. Consequently, safety precaution shall be taken. This paper presents case study in Hambalang, Bogor, West Java, Indonesia. Structural crackings are found in several places, especially at the poolside. These are appeared earlier this year, concurrently with very high intensity rainy season. Analysis is performed to check the current stability of the slope and showing that the safety factor value is 1.181. Then, reinforcement is designed as a preventive measure using retaining wall by employing bored pile coupled with sufficiently thick capping beam. The safety factor is increased to 1.553 during critical condition. This value is above the criteria of 1.5 and concluded as a safe design. Structural capacity of bored pile is also designed. Accordingly, the retaining wall is constructed on site in final stage.

Keywords: Slope Stability, Retaining Structure, Bored Pile

\section{PENDAHULUAN}

Kelongsoran adalah physical system yang terjadi dalam beberapa tahapan pada selang waktu tertentu [1][2][3]. Sejarah dari pergerakan massa tanah tersusun dari deformasi pra-keruntuhan lereng, keruntuhan itu sendiri, dan deformasi pascakeruntuhan [4]. Keruntuhan lereng adalah sebuah pergerakan tunggal yang paling signifikan pada sejarah pergerakan lereng yang mana umumnya melibatkan pembentukan pertama formasi permukaan bidang runtuh sebagaimana pergeseran dan regangan terjadi (diskrit atau terdistribusi pada zona ketebalan tertentu) [5].

Pada awal Tahun 2020, terjadi peningkatan curah hujan yang signifikan pada daerah Jakarta dan sekitarnya. BMKG mencatat pada beberapa stasiun pengukuran memiliki nilai ekstrem dibandingkan pada satu dekade terakhir, yaitu pada Stasiun Hujan Bandara Halim Perdanakusuma: 377 $\mathrm{mm} /$ hari, Stasiun Hujan TMII: $335 \mathrm{~mm} / \mathrm{hari}$, Stasiun Hujan Kembangan: 265 mm/hari; Stasiun Hujan Pulo Gadung: 260 mm/hari, Stasiun Hujan Jatiasih: $260 \mathrm{~mm} /$ hari, Stasiun Hujan Cikeas: 246 $\mathrm{mm} /$ hari, dan Stasiun Hujan Tomang: 226 mm/hari. Peristiwa ini menimbulkan masalah-masalah seperti banjir pada area hilir (yaitu Jakarta dan Bekasi), dan kelongsoran tanah pada area hulu (yaitu Kabupaten Bogor).

Pada area hulu, kelongsoran disebabkan oleh antara lain: 1) infiltrasi air hujan ke dalam lapisan tanah membuat berat jenis tanah meningkat, 2) air hujan yang masuk ke dalam lapisan tanah akan meningkatkan kadar air (water content) pada tanah sehingga menurunkan kekuatan geser pada tanah, 3) pada kasus khusus, tanah dapat mengembang saat menerima air berlebih, sehingga muncul gaya ekspansif pada tanah yang menyebabkan kelongsoran. 


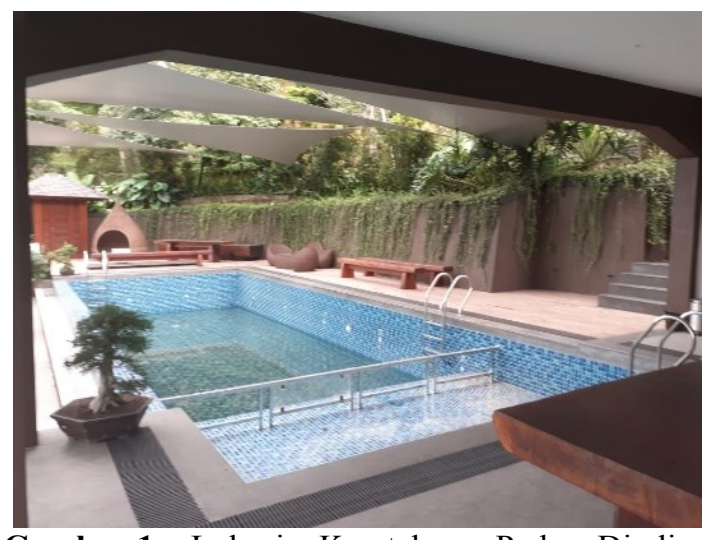

Gambar 1. Lokasi Keretakan Pada Dinding Kolam Renang

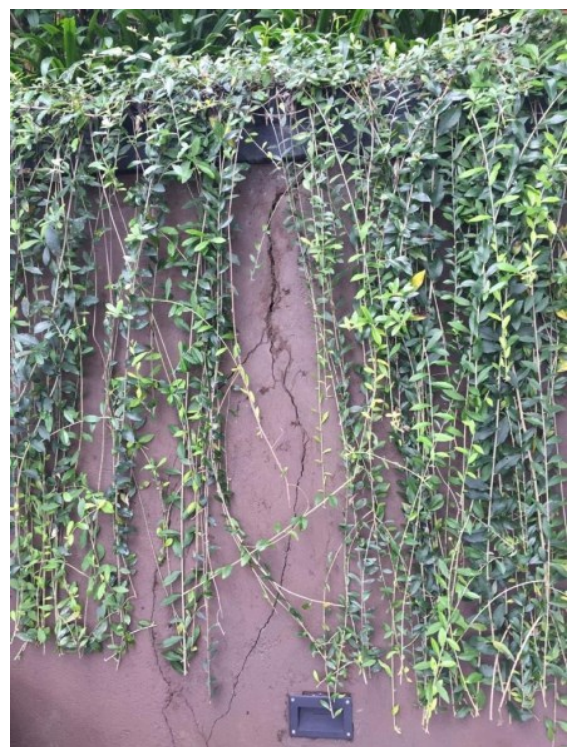

Gambar 2. Keretakan Pada Dinding Kolam Renang

Salah satu lokasi yang terdampak akibat tingginya curah hujan tersebut adalah Villa Hambalang yang terletak pada Kecamatan Hambalang, Kabupaten Bogor. Bangunan villa mengalami keretakan struktur yang baru muncul pasca hujan besar pada awal Tahun 2020 (Gambar 1). Tanah pada sisi dalam dinding menerima infiltrasi air hujan dengan intensitas yang tinggi, sehingga berat jenis tanah menjadi lebih tinggi. Selain itu, air di dalam tanah juga menjadi gaya dorongan tambahan pada dinding. Dinding tidak cukup kuat untuk menahan beban tambahan tersebut, hingga akhirnya muncul retak-retak yang terlihat oleh mata (Gambar 2).

\section{METODE}

Lokasi pengabdian masyarakat ini adalah sebuah villa yang terletak pada Kecamatan Hambalang, Kabupaten Bogor (Gambar 3 \& Gambar 4).

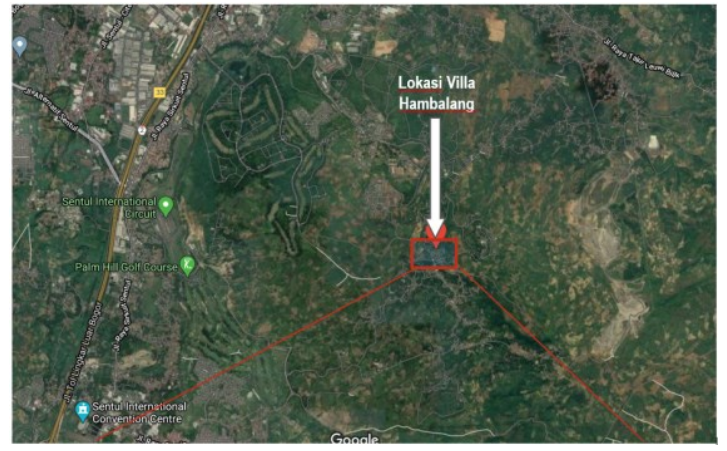

Gambar 3. Lokasi Pengabdian Masyarakat

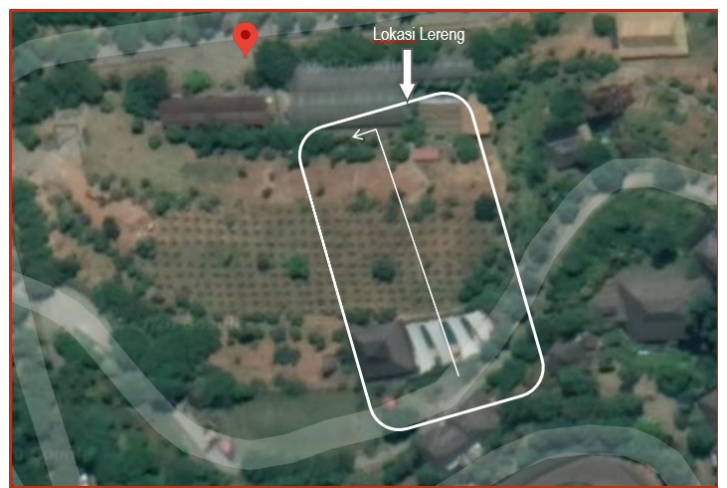

Gambar 4. Lokasi Villa Hambalang dan Tampak Atas Lereng

Pada pengabdian masyarakat ini, metode pengambilan data yang digunakan adalah dengan mengambil data primer berupa penyelidikan tanah lapangan dan laboratorium, serta survei topografi (Gambar 5 \& Gambar 6). Lokasi pengeboran tanah dilakukan seperti pada Gambar 7. Secara rinci, data yang didapatkan adalah sebagai berikut:

1. Data boring log hasil pengeboran lapangan

2. Data hasil pengujian Standard Penetration Test (SPT)

3. Data potongan melintang hasil survei topografi

Data boring log menunjukkan jenis lapisan tanah berdasarkan kedalaman. Data hasil pengujian SPT menunjukkan bacaan N-SPT dari tanah yang selanjutnya dapat dikorelasikan menjadi parameter tanah. Data hasil survey topografi selanjutnya digunakan untuk menjadi dasar dalam pemodelan dimensi lereng pada perangkat lunak.

Perangkat lunak yang digunakan dalam pengabdian masyarakat ini berbasis metode perhitungan elemen hingga (finite element), yaitu PLAXIS 2D V20 CE. 


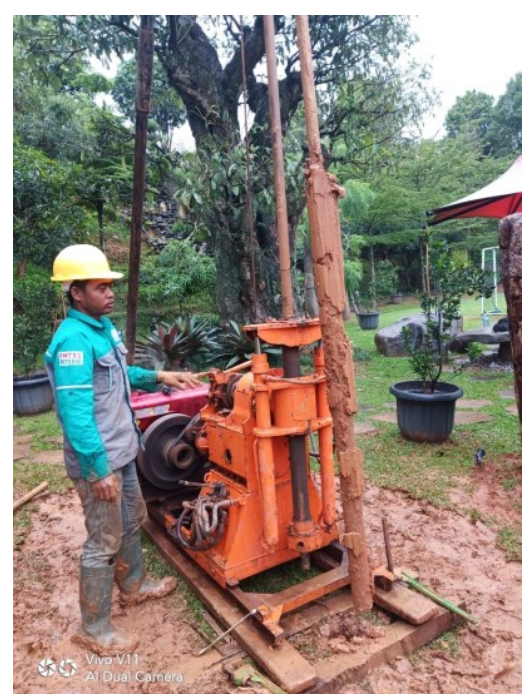

Gambar 5. Pengerjaan Deep Boring dan Standard Penetration Test (SPT)

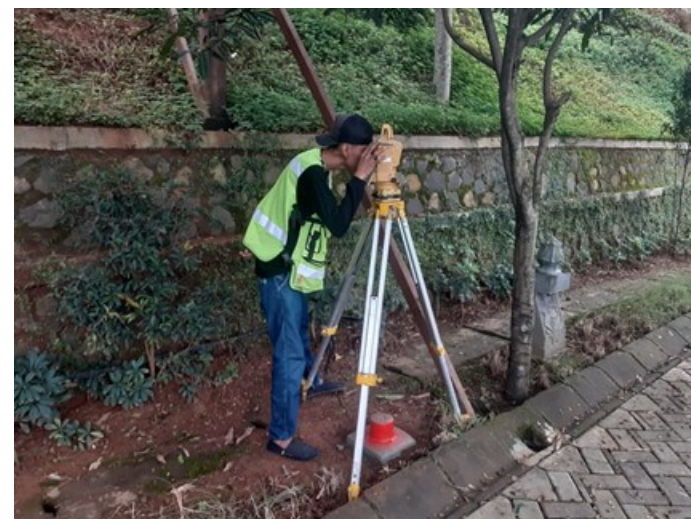

Gambar 6. Pengerjaan Survei Topografi

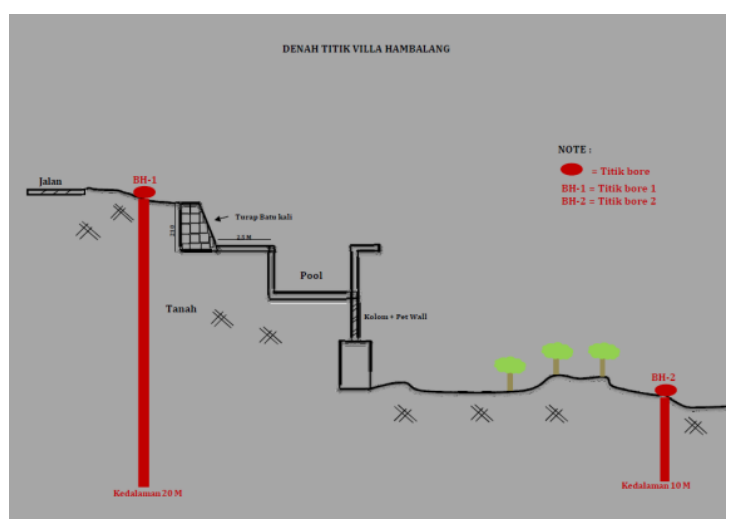

Gambar 7. Lokasi Pengeboran

\section{HASIL DAN PEMBAHASAN}

Berdasarkan hasil pengeboran, data bacaan hasil pengujian SPT kemudian dirangkum ke dalam grafik seperti tersaji dalam Gambar 8. Sedangkan hasil pengujian laboratorium dirangkum ke dalam grafik seperti tersaji dalam Gambar 9, Gambar 10, dan Gambar 11.

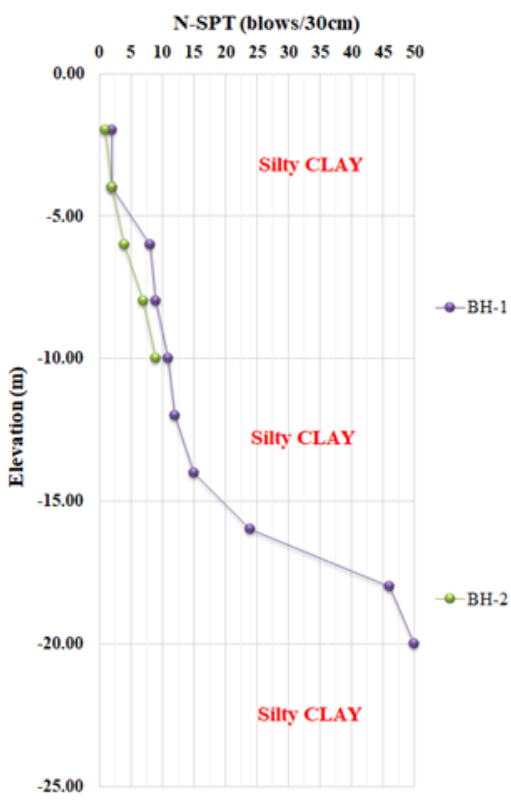

Gambar 8. Grafik Hasil Uji SPT

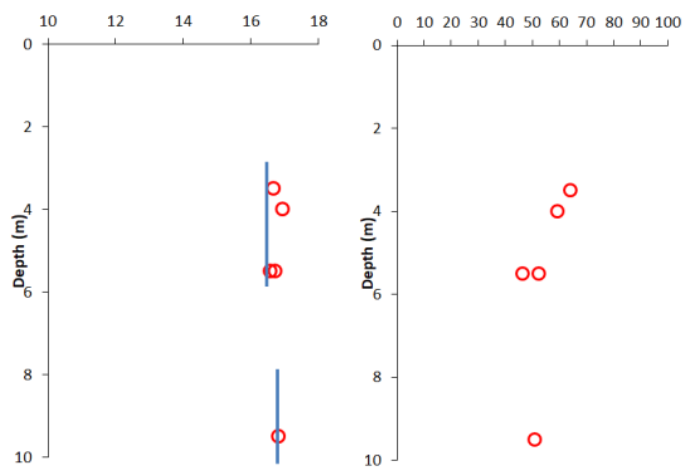

Gambar 9. Grafik Hasil Uji Lab Density ( $k N / m 3)$ dan Water Content (\%)

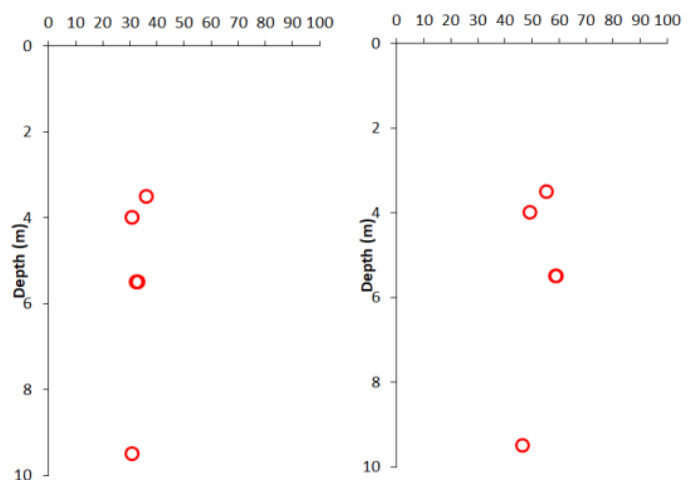

Gambar 10. Grafik Hasil Uji Lab Plastic Limit (\%) dan Plasticity Index (\%) 


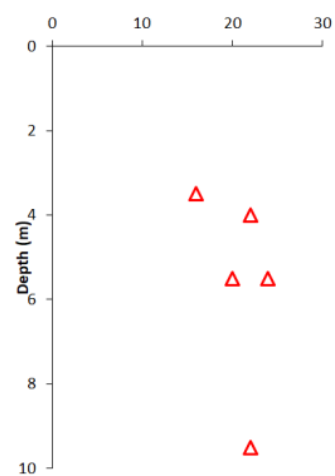

Gambar 11. Grafik Hasil Uji Lab Undrained Shear Strength $(\mathrm{kN} / \mathrm{m} 2)$

Secara umum, kondisi tanah di lokasi lereng merupakan tanah berbutir halus (fine-grained soil), tanah clay atau silt. Sifat mekanis tanah ini memiliki plastisitas, sehingga memiliki kemampuan untuk menyerap air. Saat musim hujan, tanah tersebut akan menyerap air, yang akan menjenuhkan pori-pori tanah, sehingga berat jenis tanah naik dan menambah beban pada struktur perkuatan yang ada.

Berdasarkan hasil uji lab dan lapangan tersebut, kemudian disusun sebuah parameter lapisan-lapisan tanah untuk keperluan analisis desain stabilitas lereng. Parameter tanah tersaji pada Tabel 1.

Tabel 1. Parameter Lapisan Tanah

\begin{tabular}{|c|c|c|c|c|c|c|c|}
\hline \multicolumn{2}{|c|}{ No } & 1 & 2 & 3 & 4 & 5 & 6 \\
\hline \multicolumn{2}{|c|}{ SOIL TYPE } & Silty Clay & Silty Clay & Silty Clay & Silty Clay & Silty Clay & Silty Clay \\
\hline \multirow{2}{*}{ Elev } & Top & 0.00 & -5.00 & -8.00 & -12.00 & -16.00 & -18.00 \\
\hline & Bottom & -5.00 & -8.00 & -12.00 & -16.00 & -18.00 & -25.00 \\
\hline $\mathbf{N}$ & blows/ft & 2 & 4 & 9 & 14 & 24 & 46 \\
\hline \multicolumn{2}{|c|}{ k(m/day) } & $8.64 \mathrm{E}-05$ & 8.64E-05 & 8.64E-05 & $8.64 \mathrm{E}-05$ & $8.64 \mathrm{E}-05$ & 8.64E-05 \\
\hline \multicolumn{2}{|c|}{$\gamma\left(\mathrm{kN} / \mathbf{m}^{3}\right)$} & 15 & 16 & 17 & 17 & 17 & 17 \\
\hline \multicolumn{2}{|c|}{$c^{\prime}(k P a)$} & 2 & 2 & 2 & 5 & 5 & 5 \\
\hline \multicolumn{2}{|r|}{$\phi^{\prime}$} & 19 & 20 & 23 & 25 & 28 & 32 \\
\hline \multicolumn{2}{|c|}{$\mathrm{C}_{\mathrm{u}}(\mathrm{kPa})$} & 15 & 25 & 54 & 84 & 144 & 276 \\
\hline \multicolumn{2}{|c|}{$\mathrm{E}_{\mathbf{5} 0}(\mathrm{kPa})$} & 2,300 & 3,800 & 8,600 & 10,100 & 17,300 & 33,100 \\
\hline \multicolumn{2}{|c|}{$\mathrm{E}_{\text {oed }}(\mathrm{kPa})$} & 1,840 & 3,040 & 6,880 & 8,080 & 13,840 & 26,480 \\
\hline \multicolumn{2}{|c|}{$E_{\mathrm{ur}}(\mathrm{kPa})$} & 6,900 & 11,400 & 25,800 & 30,300 & 51,900 & 99,300 \\
\hline
\end{tabular}

Desain perkuatan lereng dilakukan untuk memenuhi persyaratan minimum yang ditetapkan oleh Standar Nasional Indonesia (SNI) 8460:2017 tentang Persyaratan Perancangan Geoteknik [6]. Persyaratan berupa angka keamanan minimum, diambil sebesar FKmin $=1.5$, sesuai dengan Persyaratan minimum desain pada SNI yang disajikan pada Tabel 2.

Tabel 2. Kriteria Desain Stabilitas Lereng SNI 8460:2017

\begin{tabular}{|c|c|c|}
\hline \multirow[t]{2}{*}{ Biaya dan konsekuensi dari kegagalan lereng } & \multicolumn{2}{|c|}{$\begin{array}{l}\text { Tingkat ketidakpastian } \\
\text { kondisi analisis }\end{array}$} \\
\hline & Rendah $^{2}$ & Tinggi ${ }^{b}$ \\
\hline $\begin{array}{l}\text { Biaya perbaikan sebanding dengan biaya tambahan untuk } \\
\text { merancang lereng yang lebih konservatif }\end{array}$ & 1,25 & 1,5 \\
\hline $\begin{array}{l}\text { Biaya perbaikan lebih besar dengan biaya tambahan untuk } \\
\text { merancang lereng yang lebih konservatif }\end{array}$ & 1,5 & 2,0 atau lebih \\
\hline \multicolumn{3}{|c|}{$\begin{array}{l}{ }^{3} \text { Tingkat ketidakpastian kondisi analisis dikategorikan rendah, jika kondisi geologi dapat } \\
\text { dipahami, kondisi tanah seragam, penyelidikan tanah konsisten, lengkap dan logis } \\
\text { terhadap kondisi di lapangan } \\
\text { 'Tingkat ketidakpastian kondisi analisis dikategorikan tinggi, jika kondisi geologi sangat }\end{array}$} \\
\hline $\begin{array}{l}\text { kompleks, kondisi tanah bervatiasi, penyelidikan tanah tidak } \\
\text { diandalkan }\end{array}$ & & tidak dapat \\
\hline
\end{tabular}

Perkuatan lereng didesain dengan menggunakan tipikal desain sebagai berikut dan terlihat seperti pada Gambar 12 \& Gambar 13:

- Pondasi Tiang Bor

$$
\begin{array}{ll}
\circ & \text { Diameter } 500 \mathrm{~mm} \\
\circ & \text { Kedalaman } 12 \mathrm{~m} \\
\circ & \text { Interval } 1 \mathrm{~m}
\end{array}
$$

- Capping Beam
$\circ$ Dinding Menerus
- Tebal $700 \mathrm{~mm}$
- Tinggi $800 \mathrm{~mm}$

Berdasarkan data-data yang telah diolah, kemudian pemodelan dilakukan dengan menggunakan PLAXIS 2D V20 CE [7]. Pemodelan dibuat untuk analisis stabilitas lereng kondisi awal dan kondisi setelah dipasang perbaikan. Kondisi pada saat hujan juga dianalisis untuk kedua model tersebut. Pemodelan yang dilakukan dapat dilihat pada Gambar 14.

Analisis stabilitas dilakukan dengan menggunakan mode kalkulasi phi-c reduction sehingga didapatkan angka keamanan pada model lereng tersebut. Kemudian dihasilkan angka keamanan pada saat kondisi eksisting (tanpa perkuatan tambahan) adalah sebesar 1.312 dan pada kondisi hujan sebesar 1.181.

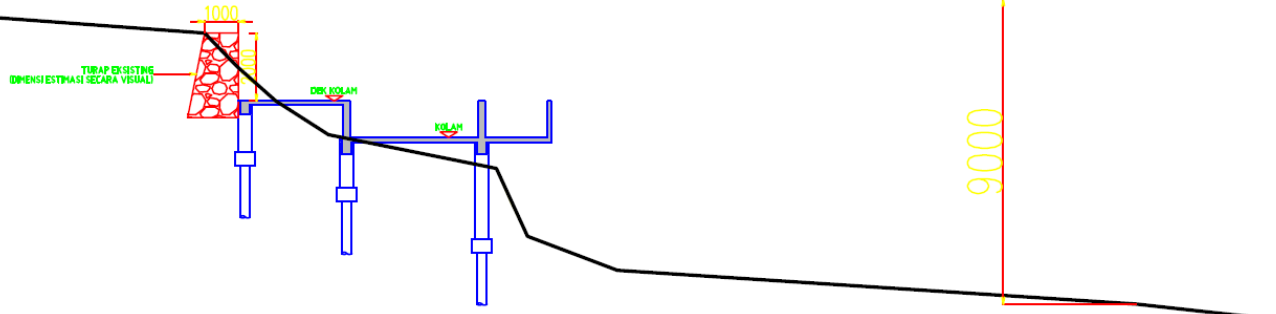

Gambar 12. Potongan Melintang Lereng untuk Analisis Desain 


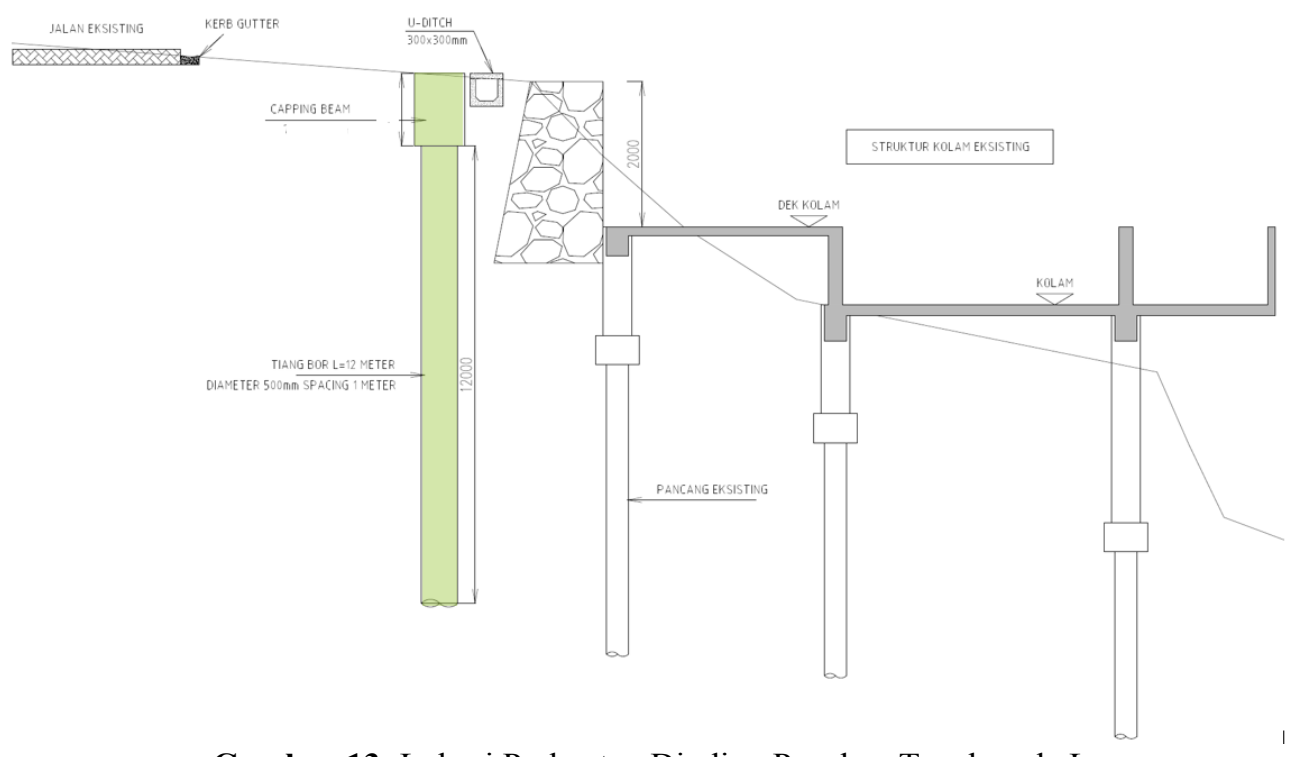

Gambar 13. Lokasi Perkuatan Dinding Penahan Tanah pada Lereng

Hasil ini lebih kecil dibanding kriteria desain minimum yang ditetapkan oleh SNI. Ini juga menunjukkan mengapa terdapat retakan-retakan pada dinding yang menunjukkan gejala awal kelongsoran.

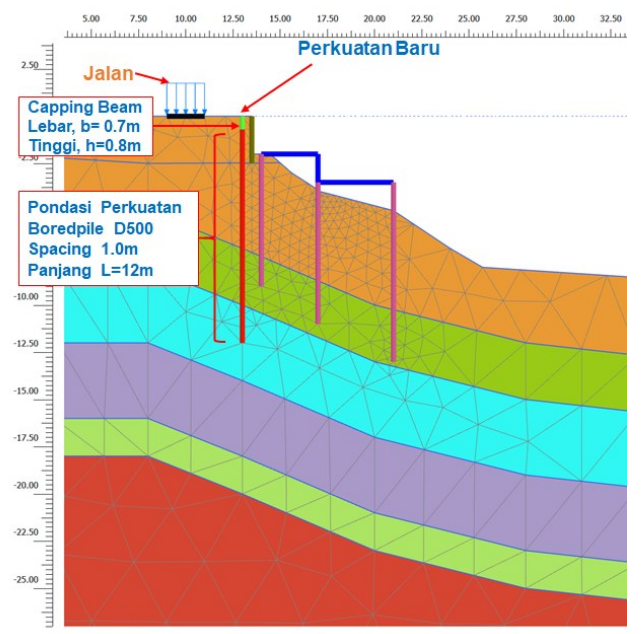

Gambar 14. Pemodelan Perkuatan Lereng Pada PLAXIS 2D V20 CE

Analisis stabilitas juga dilakukan pada model lereng yang sudah ditambahkan perkuatan. Kemudian dihasilkan angka keamanan pada kondisi dengan perkuatan adalah sebesar 1.788 dan pada kondisi hujan sebesar 1.533. Pola keruntuhan kelongsoran lereng yang didapatkan adalah seperti pada Gambar 15. Hasil ini melebihi kriteria desain stabilitas lereng minimum yang ditetapkan oleh SNI, yaitu sebesar 1.5. Sehingga perkuatan dapat dinyatakan aman dari bahaya longsor. Pola keruntuhan terlihat seperti pada Gambar 15.

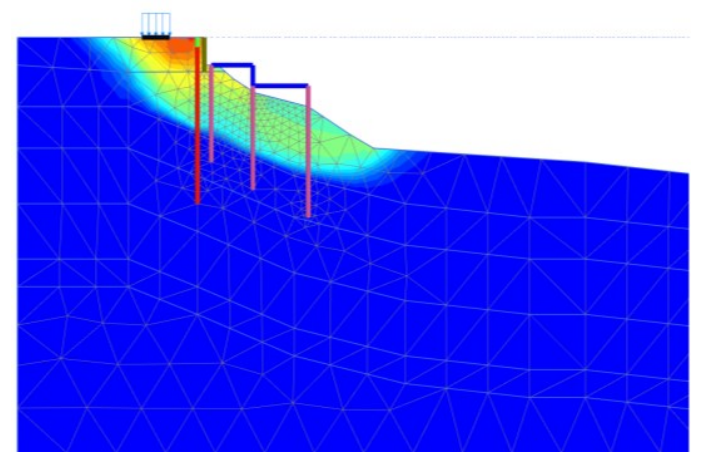

Gambar 15. Pola Keruntuhan Kelongsoran

Tahap selanjutnya, reaksi gaya dalam pada struktur perkuatan dikeluarkan untuk kemudian dilakukan perhitungan tulangan, dalam hal ini tulangan pondasi tiang bor. Dari hasil keluaran analisis, didapatkan bahwa bending momen maksimum yang terjadi pada pondasi tiang bor sebesar 141.1 kN.m (Gambar 16). Hasil rangkuman analisis tersaji dalam Tabel 3.

Tabel 3. Hasil Analisis Keluaran

\begin{tabular}{cccc}
\hline Model & Kondisi & SF & $\begin{array}{c}\text { Bending Momen } \\
\text { Tiang Bor }(\mathrm{kNm})\end{array}$ \\
\hline Kondisi eksisting & Awal & 1.312 & - \\
Hujan & 1.181 & 141.1 \\
Dengan Tiang Bor + & Awal & 1.788 & \\
Capping beam & Hujan & 1.533 & \\
\hline
\end{tabular}

Selanjutnya, pemodelan analisis tulangan pada tiang bor dilakukan dengan menggunakan perangkat lunan PCA-column [8]. Boredpile direncanakan menggunakan beton dengan kuat tekan, fc' $20 \mathrm{MPa}$. Penampang tiang didesain sehingga dapat menahan bending momen yang terjadi. Pondasi tiang didesain dengan menggunakan tulangan 12-D19, dan memiliki kapasitas bending sebesar $192 \mathrm{kNm}$ (Gambar 17). 
Hasil ini mampu menahan bending momen yang terjadi.

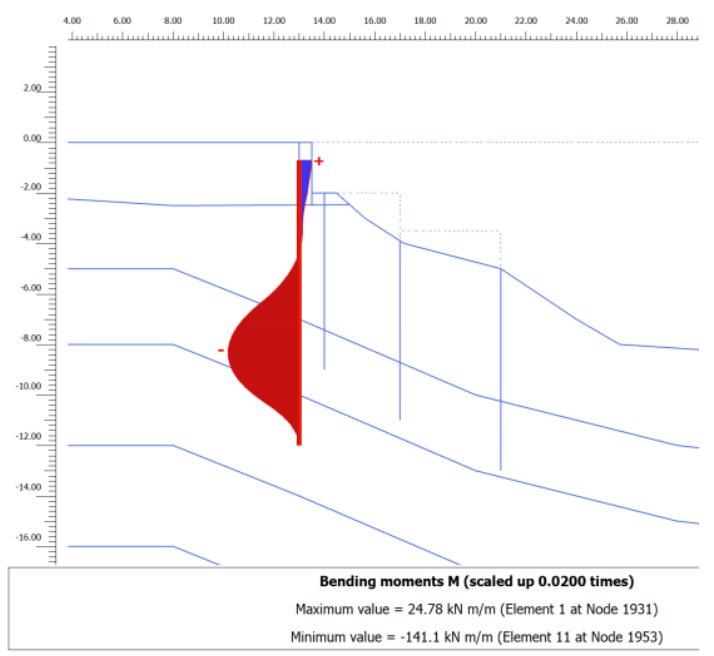

Gambar 16. Reaksi Gaya Dalam Bending Momen pada Pondasi Dinding Penahan Tanah

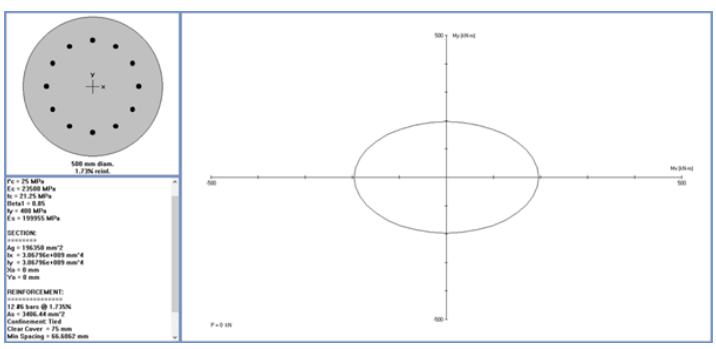

Gambar 17. Desain Penampang Tulangan Pondasi Tiang Bor

\section{OUTCOME}

Sebagai hasil dari proses pengabdian masyarakat dari hasil desain yang sudah diselesaikan, pembangunan perkuatan dinding penahan tanah dilakukan pada lokasi pekerjaan. Sebelum dilakukan, pembuatan gambar desain dilakukan agar menjadi acuan bagi pelaksana pekerjaan pembangunan di lapangan. Gambar kontruksi tersaji pada Gambar 18.

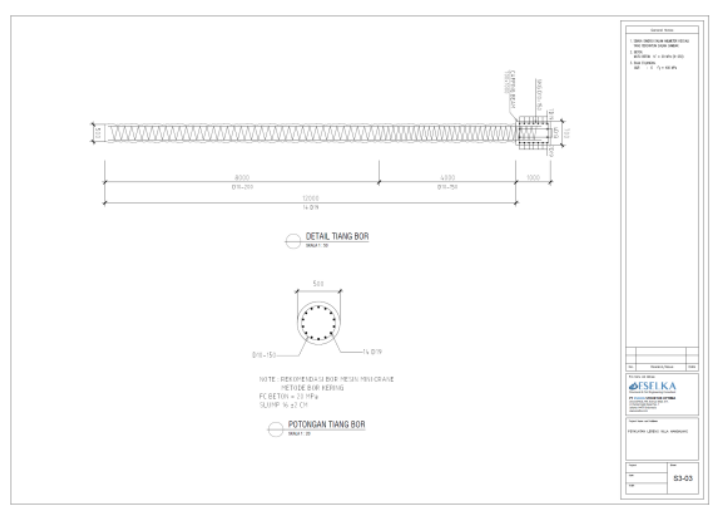

Gambar 18. Gambar Konstruksi Perkuatan Dinding Penahan Tanah
Dengan desain perkuatan yang diselesaikan akan meningkatkan keamanan lereng sehingga membawa manfaat, keselamatan dan kenyamanan bagi penghuni villa.

Selanjutnya kegiatan konstruksi dilakukan di lokasi lereng yang akan diperkuat. Konstruksi ini berlangsung selama kurang lebih 2 bulan. Dokumentasi pekerjaan konstruksi di lapangan tersaji pada Gambar 19.

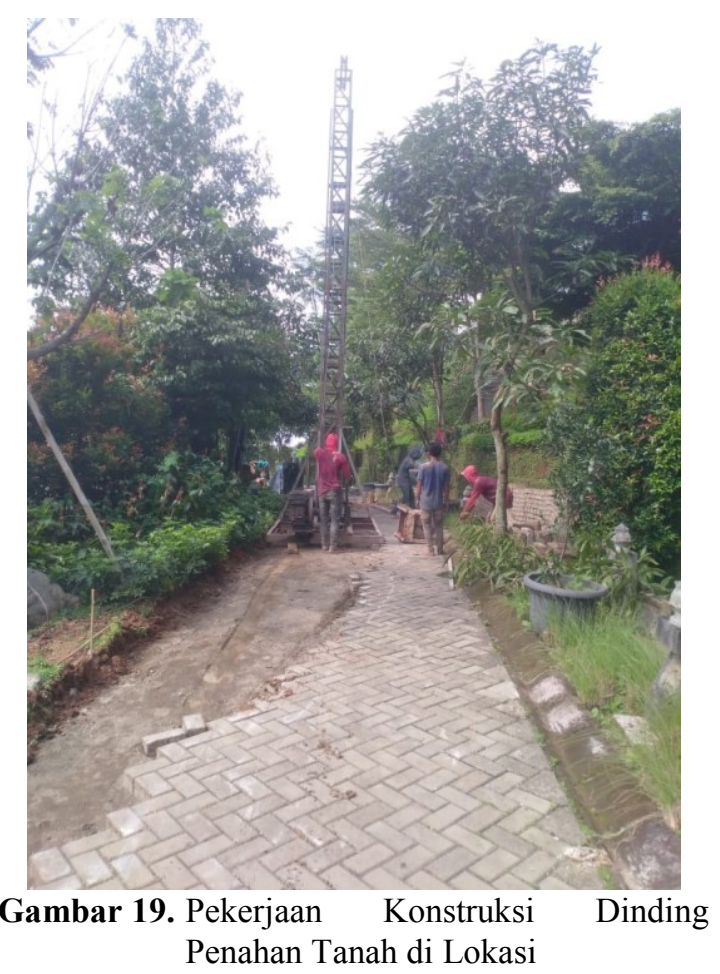

\section{KESIMPULAN}

Berdasarkan hasil analisis, pengabdian masyarakat pada lokasi Villa Hambalang Bogor menghasilkan poin-poin kesimpulan sebagai beriut:

1. Lokasi tinjauan lereng eksisting memiliki angka keamanan yang tidak memenuhi standar SNI, yaitu bernilai 1.181 pada saat kondisi kritis (hujan).

2. Desain perkuatan dinding penahan tanah dengan menggunakan sistem bored pile dan capping beam dilakukan. Hasil analisis dengan perkuatan menunjukkan bahwa angka keamanan memenuhi kriteria standar keamanan lereng, yaitu bernilai 1.533 lebih besar dari minimum 1.5.

3. Desain penulangan pondasi dilakukan dan dihitung berdasarkan gaya reaksi yang terjadi dan dibandingkan dengan perhitungan kapasitas penampang.

4. Sebagai outcome, gambar konstruksi dibuat untuk selanjutnya dikerjakan di lapangan. Dengan desain perkuatan yang diselesaikan akan meningkatkan keamanan lereng sehingga membawa manfaat, keselamatan dan kenyamanan bagi penghuni villa. 
5. Pada akhirnya, pekerjaan konstruksi dilakukan sebagai implementasi akhir dari pengabdian masyarakat.

\section{REFERENSI}

[1] Cruden, D. M., \& Varnes, D. J. (1996). Landslide types and processes. Washington, DC: Transportation Research Board, US National Research Council.

[2] Terzaghi, K. Mechanics of Landslide (Berkey Volume). Geological Society of America, New York, 1950, pp. 83-124.

[3] Leroueil, S., Locat, J., Vaunat, J., Picarelli, L., Lee, H., \& Faure, R. (1996). Geotechnical characterization of slope movements. Dalam K. Senneset, Landslides. Balkema, Rotterdam. 1996, pp. 1:53-74.
[4] Skempton, A. W., \& Hutchinson, J. N. Stability of natural slopes and embankment. Proceedings, 7th. International conference of soil mechanics and foundation engineering Mexico, State of the art volume. 1969, pp. 291-340.

[5] Morgenstern, N. R., \& Tschalenko, J. S. Microscopic structures in kaolin subjected to direct shear. Geotechnique, 1967, pp. 17:309328.

[6] Standar Nasional Indonesia. SNI 8460:2017 Persyaratan Perancangan Geoteknik. Badan Standardisasi Nasional. 2018.

[7] Plaxis BV. PLAXIS 2D Connect Edition. Bentley Systems. 2020.

[8] Portland Cement Association. pcaColumn. Skokie, Illinois, US. 2004. 